\title{
Life Satisfaction and Psychological Well-Being of Rescue Operations Participants in a Prolonged Emergency Situation
}

\author{
Yaremtchuk S. V. ${ }^{1}$ \\ ${ }^{1}$ Amur State University of Humanities and Pedagogy, Komsomolsk-on-Amur, Russia \\ Correspondence: Yaremtchuk S.V., Amur State University of Humanities and Pedagogy, Komsomolsk-on-Amur, \\ 681000, Russia. Tel: 8-924-225-4122. E-mail: svj@rambler.ru
}

Received: October 4, 2014

Accepted: November 7, 2014 Online Published: November 15, 2014

doi:10.5539/res.v6n4p174

URL: http://dx.doi.org/10.5539/res.v6n4p174

\begin{abstract}
This paper reports on study which investigated specificity of life satisfaction and psychological well-being of rescue operations participants in emergency situation. Participants of the study were military servants and emergency workers (44 males, aged 19-26) who were compared to the men not taking part in the rescue operations (44 males, aged 17-26). Data were collected with Personal Wellbeing Index and the Ryff's Scale of Psychological Well-Being. Emergency situation is considered as a challenge for personal growth.

The study proved that an emergency (in this case, flooding of large areas where people lived) creates a "challenge" for a person (rescuer or participant). As a result, there is a mobilization of physical and spiritual resources of an individual. Participants of the rescue operations are characterized by activity in the situation management; they have the ability of effective use of the life circumstances. The result is rising of the subjective and psychological well-being level.
\end{abstract}

Keywords: life satisfaction, psychological well-being, emergency situation, flood, participants of rescue operations

\section{Introduction}

The emergency situation caused by rain showers during the summer period of 2013, accompanied by the flood, led to the declaration of the state of emergency in the range of Far Eastern regions. The regions that were more extensively affected by the flood rise include Komsomolsk-on-Amur, where the state of emergency was lasting from the $21^{\text {st }}$ of August to $26^{\text {th }}$ of September 2013.

As a result of flood in the city there were damaged more than a thousand houses inhabited by over 13000 people. To conduct emergency and any other urgent works there were involved nearly 3000 people, including the rescuers of Ministry of Emergency Situations of Russia (MES) and military servants of the Armed Forces of the Russian Federation (AF RF). The MES rescuers organized the work with population of the damaged regions and at the temporary accommodation centers, conducted the extreme evacuation of the population from the deluged zones, worked on fortification and retention of the dams. The armed military servicemen units excavated the sand for backfilling washed-out roads, arranged draining ditch, executed dewatering from the building basements and near-house territories, and created pontoon-bridges across the roads.

The rescuers were in the situation when they had to overcome their own physical fatigability, their feelings and feelings of other people, involved in the emergency situation during the long-term period.

In the psychological literature the negative aspects of rescue workers lives were shown many times. There are post-traumatic stress disorder (McFarlane, 1986), phobias, anxiety, obsessive-compulsive symptoms, depression, interpersonal sensitivity, psychoticism, additional symptoms, somatization, psychological distress (Lee et al., 2002), risk of chronic symptomatic distress (Weiss et al., 1999), burnout (Agapitova \& Levina, 2012; Moushastaya, 2007). E. N. Ashanina and D. V. Kulakov (2011) came to conclusion that the disordered psychological states are widely-distributed among the employees the State fire service of the Ministry of Emergency Situations of Russia (both in the everyday life and after participation in liquidation of large-scale emergency situations (ESs)). Psycho-emotional disorders, asthenia and neurotic symptoms are observed in the majority of them. J. Park (2008) revealed that members of the regular forces are unsatisfied with their lives, especially if they take part in disaster relief. 
Along with this, it is shown in the psychological literature that the reactions of the emergency workers to the stress-producing conditions can be different. There are data about the expressiveness of the negative emotional reactions. It is significantly lower in male rescue workers than in male primary victims (Tivis et al., 2002), some studies found a much higher spreading of post-traumatic stress disorder among non-professional workers (Everly, Perrin, \& Everly, 2008).

The explanations to this are found in the career selection of emergency workers, their preparedness and experience (Tivis et al., 2002). The studies discover that rescue workers have learned to deal with traumatic events and to take them in stride. Risk of disorder is significantly lower when the exposure to life threatening situations is accompanied by high perceived social support (Everly, Perrin, \& Everly, 2008).

The comparative studies show that the negative affect of emergency situation is intensified if the rescue workers are shy, inhibited, uncertain about their identity, reluctant to take leadership. They have global cognitive style, believe their fate is determined by the factors beyond their control, and cope with the critical incident trauma caused by emotional suppression and wishful thinking (Weiss et al., 1996). Conversely, the risk of unfavorable effect is reducing with the expense of such personal peculiarities, as persistence, ability to make decisions, rational understanding of one's own actions, good organization, ability to create one's own communication circle, ability to communicate, and ability to control oneself (Psihologija jekstremal'nyh situacij dlja spasatelej i pozharnyh, 2007).

This is demonstrated in the Kasyanik study (2014). In emergencies, leadership qualities help to quickly build social ties between strangers, to generate new solutions to current problems. Lifeguard leader defies panic behavior, he or she makes conscious choices of actions. A similar position is held by a Russian scientist Doroshenko (2012), who made a complex analysis of international experience in the conduction of lifeguard professional activities. Viability should be formed both in a professional rescuer and in an average citizen.

For some people the emergency conditions can have unfavorable consequences, while for the others it launches active and difficulty-overcoming behaviour, and emergency situation serves as a point of development. The negative factors of situation evoke their human activity, directed on the problems overcoming, generate the demand to search and to find the ways of overcoming obstacles, and develop strategies of getting over it (Lichnost' $v$ jekstremal'nyh uslovijah i krizisnyh situacijah zhiznedejatel'nosti, 2011).

Thus, in the study of E. B. Vesna and O. S. Shirjaeva (2009) it was shown, that the psychological well-being of people, who live in the extreme climatic conditions, is increased. The predominance of the positive emotions, meaning in life, self-realization satisfaction, feeling of the personal growth, internal support of their values and convictions, perception of themselves as strong personalities, higher indicators of spontaneity, self-respect, and feeling of control over their own life is typical for them. The author explains this by the necessity of the constant appeal to their psychological resources in the extreme conditions, expansion of the repertoire and ways of interaction with the environment and self-development.

G. V. Litvinova (2011) also states that the extreme conditions cause the ambivalent effect on the person. On the one part, the emotional sphere of people turns out to be under the influence of feeling insecure, and on the other part, it promotes the display of the positive personal traits and mobilization of internal resources. M. Kloep, L. Hendry, D. Saunders (2009) state that each time an individual meets a challenge, the system of resources comes into a state of imbalance; the individual is forced to adapt his or her resources. R. Dodge, A. Daly, J. Huyton, L. Sanders (2012) consider that when individuals have more challenges than the psychological, social and physical resources, their well-being changes.

The emergency situation embodies conditions, when individuals have more challenges than the resources.

In connection to this, the subjective and psychological well-being of the participants of rescuing operations, in comparison with the state of males that are not involved into the rescuing situations, became the aim of this study.

The main tasks set and solved in this study are:

To identify the characteristics of the psychological well-being and life satisfaction of rescuers involved in the conduction of rescue and other operations in an emergency situation;

To establish if there is a relationship between the components of subjective and psychological well-being that reflect the specific characteristics of the rescuers, which distinguish them from people not participating in the rescuing works.

Testable hypotheses were: 
Rescuers in extreme situation launch active behavior (to overcome difficulties), which is manifested in the strengthening of psychological well-being and enhancing of satisfaction with the separate components of life;

Psychological and subjective well-being are conjugate phenomena that manifest themselves in a consistent change of their components in the conditions of normal living conditions absence.

\section{Method and Participants}

Participants of the study were military servants of AF RF (22 males, aged 19-25) and emergency workers of MES (22 males, aged 22-26). The control group included men who didn't take part in the rescue operations: students, who were in the city in the time of emergency situation and didn't feel its effect (22 males, aged 17-21), and military servants, who didn't participate is the rescuing (22 males, aged 18-26).

Data collection was carried out during the week after the emergency state cancellation. Conscripts, who have not participated in the rescue operations, because they were the soldiers of the next draft, were interrogated two months after the emergency state cancellation, because at the time of emergency all the forces of the army and of the Ministry of Emergency Situations have been involved into its solving.

Data were collected with the Personal Wellbeing Index (PWI) and the Scales of Psychological Well-Being (SPWB).

Life satisfaction was measured with the Personal Wellbeing Index (PWI) (Eckersley et al., 2003) that was translated into Russian by Dr. Ekaterina Uglanova with assistance of faculty and students of Departement of Sociology at Saint-Petersburg Branch of State University-Higher School of Economics (International Wellbeing Group, 2005). The scale comprises seven items measuring satisfaction with life domains: Standard of Living, Personal Health, Achieving in Life, Personal Relationships, Personal Safety, Community-Connectedness, and Future Security. An additional item was included into probe participants' satisfaction with their life on the whole. Participants were required to indicate their satisfaction on a scale ranging from 0 (completely dissatisfied) to 10 (completely satisfied). All results were converted to a $0-100$ format as prescribed by the manual (International Wellbeing Group, 2006). The mean of the domain scores was the measure of Subjective well-being (PWI-index).

A standard PWI is used, which was conducted in written form.

Use of 0-10 Likert Response Scale

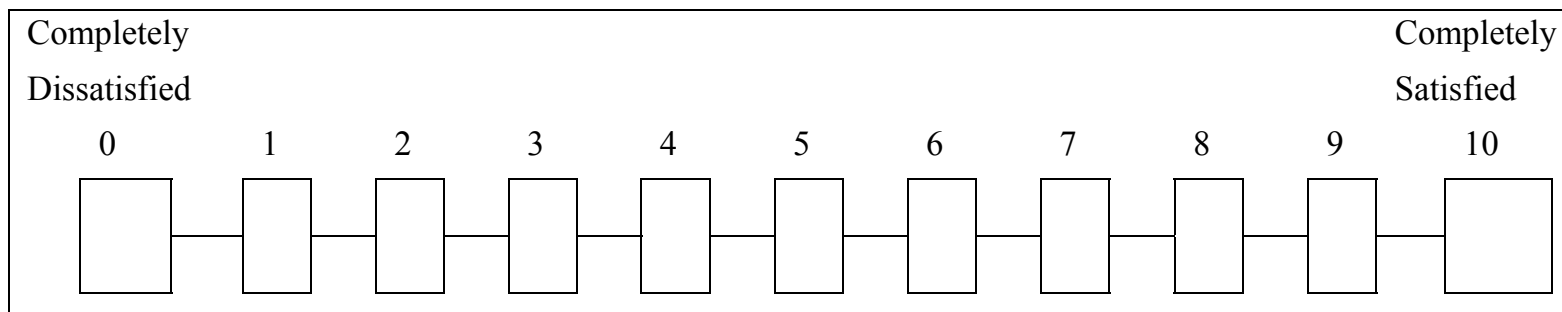

Data on the validity of the PWI methodology, obtained by the author on a sample of 364 people. The Table 1 represents the regression of the seven domains of the Personal Wellbeing Index to "Satisfaction with life as a whole". The analyze includes a standard multiple regression with a $\mathrm{N}$ of 364 . The $\mathrm{sr}^{2}$ statistic describes the amount of unique variations contributed into each domain.

Table 1 . Construct validity of PWI (Russian version, $\mathrm{N}=364$ )

\begin{tabular}{|c|c|c|c|c|c|c|c|c|c|c|}
\hline & 1 & 2 & 3 & 4 & 5 & 6 & 7 & $\mathrm{~B}$ & $\beta$ & $\mathrm{sr}^{2}$ \\
\hline \multicolumn{11}{|l|}{ 1. Life on the whole } \\
\hline 2. Standard of Living & 0.54 & & & & & & & $0.22 * *$ & 0.21 & 0.297 \\
\hline 3. Personal Health & 0.54 & 0.49 & & & & & & $0.16^{* *}$ & 0.14 & 0.289 \\
\hline 4. Achieving in Life & 0.39 & 0.39 & 0.46 & & & & & 0.01 & 0.01 & 0.158 \\
\hline $\begin{array}{l}\text { 5. Personal } \\
\text { Relationships }\end{array}$ & 0.48 & 0.39 & 0.47 & 0.37 & & & & $0.18 * *$ & 0.16 & 0.229 \\
\hline
\end{tabular}




\begin{tabular}{|c|c|c|c|c|c|c|c|c|c|c|}
\hline 6. Personal Safety & 0.19 & 0.10 & 0.18 & 0.23 & 0.22 & & & 0.04 & 0.02 & 0.037 \\
\hline $\begin{array}{l}7 . \\
\text { Community-Connected } \\
\text { ness }\end{array}$ & 0.41 & 0.32 & 0.36 & 0.32 & 0.45 & 0.13 & & $0.08^{*}$ & 0.06 & 0.163 \\
\hline 8. Future Security & 0.57 & 0.49 & 0.55 & 0.46 & 0.34 & 0.17 & 0.41 & $\begin{array}{l}0.27 * * \\
\text { Adj. } \mathbf{R}^{2} \\
0.479\end{array}$ & $\begin{array}{l}0.26 \\
\mathbf{R} \\
0.699\end{array}$ & $\begin{array}{l}0.310 \\
\mathbf{R}^{2} \\
0.489\end{array}$ \\
\hline
\end{tabular}

${ }^{* *} \mathrm{p}<.01 ; * \mathrm{p}<.05$

The Scales of Psychological Well-Being (SPWB), which was developed by C. D. Ryff (1989) and translated into Russian by T.D. Shevelenkova, P.P. Fesenko (2005), has six components which include Positive relations with others (building ties with others in relationships, having satisfying personal relationships where empathy and intimacy are expressed), Autonomy (the sense of self-determination, self-direction as guided by one's own socially accepted internal standards), Environmental mastery (the capacity of individual to effectively manage his or her life and the world according to one's own needs), Personal growth (the insight into one's own potential for self-development, the sense that he or she continues to grow and to develop oneself as a person), Purpose in life (goals and beliefs that affirm a sense of direction and meaning in life), and Self-acceptance (a positive and acceptant attitude toward aspects of oneself in past and present). The highest score that can be obtained from each of the components is 84 , the lowest is 14 .

Data on the validity and reliability of the SPBI methodology, obtained by Shevelenkova and Fesenko (Shevelenkova, 2005) (Table 2, Table 3).

Table 2. Test-retest reliability of SPBI (Russian version by Shevelenkova and Fesenko, N=272)

\begin{tabular}{llcl}
\hline \multirow{2}{*}{ Components of SPWB } & \multicolumn{2}{c}{ Means } & $\begin{array}{l}\text { Correlation } \\
\text { coefficient }\end{array}$ \\
\cline { 2 - 4 } & $\mathbf{1}$ & $\mathbf{2}$ & $0.829^{*}$ \\
\hline Positive relations with others & 62.5 & 61.11 & $0.812^{*}$ \\
Autonomy & 60.61 & 58.27 & $0.793^{*}$ \\
Environmental mastery & 58.55 & 56.00 & $0.801^{*}$ \\
Personal growth & 64.94 & 64.00 & $0.901^{*}$ \\
Purpose in life & 63.00 & 61.33 & $0.894^{*}$ \\
Self-acceptance & 61.55 & 59.94 & \\
\hline
\end{tabular}

$* \mathrm{p}<01$

Table 3. Internal consistency of scales SPBI (Russian version by Shevelenkova and Fesenko, N=272)

\begin{tabular}{ll}
\hline Components of SPWB & Cronbach's alpha \\
\hline Self-acceptance & 0.5199 \\
Positive relations with others & 0.4922 \\
Autonomy & 0.2038 \\
Environmental mastery & 0.4639 \\
Purpose in life & 0.6982 \\
Personal growth & 0.2399 \\
\hline
\end{tabular}

The difference between various groups was detected through the use of Mann-Whitney t test. Spearman's rank correlation analysis was used to find the associates between the scales of PWI and SPWB. 


\section{Results}

The compare of means of satisfaction with aspects of life by participants of rescue operations and men, who didn't take part in them, are presented in Table 4.

Table 4. Comparing across domains of PWI

\begin{tabular}{lllll}
\hline Domains of PWI & \multicolumn{2}{c}{ Means } & t test & p-level \\
\cline { 2 - 4 } & $\begin{array}{l}\text { Participants } \\
\text { rescue operations }\end{array}$ & Control group & \\
\hline PWI & $\mathbf{8 4 . 5}$ & $\mathbf{6 9 . 4}$ & $\mathbf{5 . 2 1 4}$ & $\mathbf{0 . 0 1 6}$ \\
Standard of Living & 76.8 & 74.3 & 0.018 & 0.986 \\
Personal Health & 88.1 & 78.1 & 1.892 & 0.062 \\
Achieving in Life & 80.2 & 75.5 & 1.536 & 0.128 \\
Personal Relationships & 88.9 & 87.3 & -0.370 & 0.712 \\
Personal Safety & $\mathbf{8 9 . 5}$ & $\mathbf{7 8 . 9}$ & $\mathbf{2 . 3 4 7}$ & $\mathbf{0 . 0 2 1}$ \\
Community-Connectedness & $\mathbf{8 4 . 5}$ & $\mathbf{6 8 . 1}$ & $\mathbf{2 . 1 1 9}$ & $\mathbf{0 . 0 3 7}$ \\
Future Security & 83.2 & 73.0 & 1.521 & 0.132 \\
Life on the whole & 82.5 & 76.3 & 0.685 & 0.495 \\
\hline
\end{tabular}

According to all methodical indicators, the participants of rescuing operations demonstrate higher values, than the control group. The significant differences were detected according to the domains "Personal Safety" $(\mathrm{p}=0.021)$ and "Community-Connectedness" $(\mathrm{p}=0.030)$, and also by PWI $(\mathrm{p} \leq 0.0001)$.

The data in accordance with SPWB are represented in the table 5.

Table 5. Comparing of the SPWB components

\begin{tabular}{|c|c|c|c|c|}
\hline \multirow[b]{2}{*}{ Components of SPWB } & \multicolumn{2}{|c|}{ Means } & \multirow[b]{2}{*}{ t test } & \multirow[b]{2}{*}{ p-level } \\
\hline & $\begin{array}{l}\text { Participants of } \\
\text { rescue operations }\end{array}$ & Control group & & \\
\hline Positive relations with others & 61.7 & 59.2 & 1.456 & 0.149 \\
\hline Autonomy & 56.8 & 56.7 & 0.109 & 0.914 \\
\hline Environmental mastery & 62.0 & 58.2 & 2.358 & 0.021 \\
\hline Personal growth & 59.4 & 59.7 & -0.193 & 0.848 \\
\hline Purpose in life & 63.5 & 59.6 & 1.869 & 0.065 \\
\hline Self-acceptance & 61.3 & 59.6 & 0.964 & 0.338 \\
\hline
\end{tabular}

Differences between groups were generally not large, but they were sometimes statistically significant. Participants of rescue operations tended to have more feeling of power and competence in managing the environment ("Environmental mastery").

Table 6 presents results of correlation analysis between Domains of PWI and Environmental mastery. 
Table 6. Correlation between domains of PWI and environmental mastery

\begin{tabular}{|c|c|c|}
\hline \multirow[b]{2}{*}{ Domains of PWI } & \multicolumn{2}{|c|}{ Environmental mastery } \\
\hline & $\begin{array}{l}\text { Participants of } \\
\text { operations }\end{array}$ & rescue Control group \\
\hline PWI & 0.262 & 0.046 \\
\hline Standard of Living & 0.140 & 0.065 \\
\hline Personal Health & 0.120 & -0.090 \\
\hline Achieving in Life & 0.010 & 0.062 \\
\hline Personal Relationships & 0.238 & 0.094 \\
\hline Personal Safety & $0.433 *$ & 0.258 \\
\hline Community-Connectedness & $0.490 *$ & 0.129 \\
\hline Future Security & 0.170 & 0.265 \\
\hline Life as a whole & 0.093 & 0.163 \\
\hline
\end{tabular}

$* \mathrm{p} \leq 0.001$

Analyzing the correlation (table 3), the significant correlations coefficients between Environmental mastery and Personal Safety $(\mathrm{r}=0.433)$ and Community-Connectedness $(\mathrm{r}=0.490)$ in the group of participants of rescue operations were found. The result indicated that environmental mastery of rescue operation participants demonstrated positive associations with their personal safety evaluation and satisfaction with their community (connectedness). No significant relations between Environmental mastery and satisfaction with all aspects of life were found in the control group.

\section{Discussion}

The study confirmed that participants of rescue operations show greater satisfaction with their personal safety and community-connectedness. They feel themselves safer and more involved in the community than other people.

Feeling of personal safety in the emergency situation is probably achieved by the management of this situation. It is known that one of the internal factors, determining subjective well-being, is perceived as the control one. In earlier issues there was found the internal locus of control correlated with life satisfaction (González et al., 2004; Wigert, 2001; Kulshresta \& Sen, 2006; Stocks, April, \& Lynton, 2012). People who believe that events and outcomes are within their immediate control are more satisfied with their lives than people who perceive events and outcomes to be caused by external reasons. In case, when a person can participate in the decreasing of bad outcomes of external influence, his or her control over one's environment and life satisfaction increases.

During the assessment of satisfaction with life men report the lowest satisfaction in the sphere of their community (connectedness). Community relationships presuppose inclusion in the community, that doesn't always depend on a person, and that reduces the men's satisfaction with this aspect of life. But what concerns participants of rescue operations, they demonstrate significant difference with other men. They are more satisfied with that sphere because their rescue works were accompanied by the wide interaction with people around. They act for the benefit of community and communicate with people, who live or just are near to them. Except for this, their actions were highly evaluated by the people around, who expressed gratitude and care about their state and well-being.

The active involvement into the action of rescuing the city also led to the significant increase of sense of mastery and competence in managing the environment. This research shows that participants of rescue operations see themselves as controlling complex of external activities, making effective use of the surrounding opportunities. They have greater sense of control over external world, than ordinary people.

Environmental mastery of participants of rescue operations was associated with their evaluation of personal safety and satisfaction with being a part of their community. This confirms the conditionality of higher meanings according to the indicators of involvement into the actions on city rescuing. In the control group such correlation was not detected. Their environmental mastery doesn't determine satisfaction with none of the aspects of life.

The results of the study show that the involvement into the active actions on the execution of rescuing operations 
is accompanied with intensification of the subjective and psychological well-being and expansion of access to the personal resources. The emergency situations raise the demands to a person, involved in it, create "the challenge" for all personal characteristics and resources of a human. In such situation the mobilization of all personal resources, expansion of one's abilities, directed on overcoming conditions, the ability of a person to find himself/herself take place. The participation in rescuing operations is connected with solution of real tasks, directed on the help for the other people, execution of actions meaningful for others. That leads to intensive activity and situation control, ability to effectively use life conditions of the participants of rescuing operations.

Thus, the emergency situation can be considered as the specific conditions, creating challenge for the person, requiring the maximal tension of personal resources from individual, actualization of personal qualities and personal re-development. This results in the increasing of the level of subjective and psychological well-being.

\section{Acknowledgement}

This research was supported by The Ministry of Education and Science of the Russian Federation within the scope of the base section of the State task in the sphere of scientific activity, project No.2028.

\section{References}

Agapitova, Y. S., \& Levina, N. A. (2012). Psychological resources of vitality and the problem of the prevention of emotional burning out at the staff of the ministry of emergency situation. Social'no-jekonomicheskie javlenija i processy. Tambovskij gosudarstvennyj universitet im. G.R. Derzhavina (Tambov), 7-8, 238-243.

Ashanina, E. N., \& Kulakov, D. V. (2011). Expressiveness and features of desadapted psychological statuses among the employees of the State fire service of the Ministry of Emergency situations of Russia. Uchenye zapiski universiteta imeni P.F. Lesgafta, 79(9), 24-28.

Casas, F., González, M., Figuer, C., \& Coenders, G. (2004). Subjective Well-Being, Values and Goal Achievement: The Case of Planned Versus by Chance Searches on the Internet. Social Indicators Research, 66, 123-142. http://dx.doi.org/10.1023/B:SOCI.0000007492.61737.46

Chumaeva, Ju. V. (2008). Psihofiziologicheskaja ocenka jeffektivnosti reabilitacii pozharnyh—Spasatelej. Aktual'nye problemy transportnoj mediciny, 3(13), 34-39.

Cummins, R. A., Eckersley, R., Pallant, J., Van Vugt, J., \& Misajon, R. (2003). Developing a national index of subjective wellbeing: The Australian Unity Wellbeing Index. Social Indicators Research, 64, 159-190. http://dx.doi.org/10.1023/A:1024704320683

Dodge, R., Daly, A., Huyton, J., \& Sanders, L. (2012). The challenge of defining wellbeing. International Journal of Wellbeing, 2(3), 222-235. http://dx.doi.org/10.5502/ijw.v2i3.4

Doroshenko, T. V. (2012). Zhiznestojkost' lichnosti v uslovijah chrezvychajnoj situacii kak predmet issledovanija na primere professii "spasatel" v sisteme MChS Rossii. Lichnost'v jekstremal'nyh uslovijah i krizisnyh situacijah zhiznedejatel'nosti, 2, 34-37.

Eliseeva, I. N. (2014). Osnovnye jetapy i problemy formirovanija jekstremal'noj psihologii v rossii. Znanie. Ponimanie. Umenie, 3, 339-345.

Everly, G. S., Perrin, A. P., \& Everly, G. S. III. (2008). Psychological Issues in Escape, Rescue, and Survival in the Wake of Disaster. Mental Health, 12(1), 21-30.

International Wellbeing Group. (2005). International wellbeing index: Translation made by Dr. Ekaterina Uglanova. Retrieved from http://www.deakin.edu.au/research/acqol/iwbg/translations/index.php

International Wellbeing Group. (2006). Personal wellbeing index. Australian centre on quality of life. Melburne: Deakin University.

Kas'janik, P. M. (2014). Sovremennye zarubezhnye issledovanija povedenija tolpy v jekstremal'nyh situacijah. Prikladnaja juridicheskaja psihologija, 3, 157-164.

Kloep, M., Hendry, L., \& Saunders, D. (2009). A new perspective on human development. Conference of the International Journal of Arts and Sciences, 1(6), 332-343.

Kremen', M. A., Gerasimchik, A. P., \& Bogdanovich, A. B. (2013). Inzhenernaja psihologija v sisteme podgotovki specialistov po preduprezhdeniju i likvidacii chrezvychajnyh situacij. Vestnik Komandno-inzhenernogo instituta MChS Respubliki Belarus', 2(18), 190-198.

Kulshresta, U., \& Sen, C. (2006). Subjective well-being in relation to emotional intelligence and locus of control among executives. Journal of the Indian Academy of Applied Psychology, 32, 93-98. 
Liao, S. C., Lee, M. B., Lee, Y. J., Weng, T, Shih, F. Y., \& Ma, M. H. (2002). Association of psychological distress with psychological factors in rescue workers within two months after a major earthquake. Journal of the Formosan Medical Association, 101(3), 169-176.

Lichnost' v jekstremal'nyh uslovijah i krizisnyh situacijah zhiznedejatel'nosti. (2011). Vladivostok: Maritime State University named after G.I. Nevelskoi.

Litvinova, G. V. (2011). Osobennosti psihologicheskogo blagopoluchija podrostkov (regional'nyj aspekt). In Problemy $i$ perspektivy razvitija pedagogiki $i$ psihologii: materialy mezhdunarodnoj zaochnoj nauchno-prakticheskoj konferencii. Chast'I. (24 oktjabrja 2011 g.) (pp. 84-93). Novosibirsk: Apriori.

Marmar, C. R., Weiss, D. S., Metzler, T. J., \& Delucchi, K. L. (1996). Characteristics of emergency services personnel related to peritraumatic dissociation during critical incident exposure. American Journal of Psychiatry, 153, 94-102.

Marmar, C. R., Weiss, D. S., Metzler, T. J., Delucchi, K. L., Best, S. R., \& Wentworth, K. A. (1999). Longitudinal course and predictors of continuing distress following critical incident exposure in emergency services personnel. The Journal of Nervous and Mental Diseases, 187, 15-22. http://dx.doi.org/10.1097/00005053-199901000-00004

McFarlane, A. C. (1986). Long-term psychiatric morbidity after a natural disaster. The Medical Journal of Australia, 145, 561-563.

Moushastaya, N. P. (2007). Syndrome of emotional burning out at employees of the Ministry of Emergency Measures as a parameter professional. Russian Psychological Journal, 4(2), 50-51.

North, C. S., Tivis, L., McMillen, J. C., Pfefferbaum, B., Spitznagel, E. L., Cox, J., ... Smith, E. M. (2002). Psychiatric Disorders in Rescue Workers After the Oklahoma City Bombing. American Journal of Psychiatry, 159, 857-859. http://dx.doi.org/10.1176/appi.ajp.159.5.857

Park, J. (2008). A profile of the Canadian Forces. Perspectives on Labour and Income, 9(7), 17-30.

Psihologija jekstremal'nyh situacij dlja spasatelej i pozharnyh. (2007). Moskva: Smysl.

Ryff, C. D. (1989). Happiness is everything, or is it explorations on the meaning of psychological well-being. Journal of Personality and Social Psychology, 57(6), 1069-1081. http://dx.doi.org/10.1037/0022-3514.57.6.1069

Shevelenkova, T. D., \& Fesenko, P. P. (2005). Psihologicheskoe blagopoluchie lichnosti (obzor osnovnyh koncepcij i metodika issledovanija). Psihologicheskaja diagnostika, 3, 95-129.

Stocks, A., April, K. A., \& Lynton, N. (2012). Locus of control and subjective well-being: A cross-cultural study in China and Southern Africa. Problems and Perspectives in Management, 10(1), 17-25.

Vesna, E. B., \& Shirjaeva, O. S. (2009). Psihologicheskoe blagopoluchie lichnosti v jekstremal'nyh prirodno-klimaticheskih uslovijah zhiznedejatel'nosti. Vestnik Jaroslavskogo gosudarstvennogo universiteta im. P. G. Demidova. Ser. Gumanitarnye nauki, 2, 31-41.

Wigert, L. R. (2001). An investigation of the relationships among personality traits, locus of control, religious orientation, and life satisfaction: A path analytical study. Lincoln: University of Nebraska.

\section{Copyrights}

Copyright for this article is retained by the author(s), with first publication rights granted to the journal.

This is an open-access article distributed under the terms and conditions of the Creative Commons Attribution license (http://creativecommons.org/licenses/by/3.0/). 